\title{
RESEARCH PAPER \\ Influence of a spray-dried fat enriched with EPA and DHA on the fatty acid composition of sow milk
}

\author{
Mariola Grez¹, Mónica Gandarillas ${ }^{1,2}$, Fernando González, and Einar \\ Vargas-Bello-Pérez ${ }^{1}$ \\ ${ }^{1}$ Pontificia Universidad Católica de Chile, Facultad de Agronomía e Ingeniería Forestal, Departamento de \\ Ciencias Animales. Santiago, Chile, Casilla-306. P. O. Box 6904411. \\ ${ }^{2}$ Universidad Austral de Chile, Facultad de Ciencias Agrarias, Instituto de Producción Animal. \\ Independencia 641, Campus Isla Teja Valdivia. Postal Code: 5110566.
}

\begin{abstract}
M. Grez, M. Gandarillas, F. González, and E. Vargas-Bello-Pérez. 2016. Influence of a spray-dried fat enriched with EPA and DHA on the fatty acid composition of sow milk. Cien. Inv. Agr. 43(3):347-355. Supplementation with eicosapentaenoic and docosahexaenoic acids (EPA and DHA) through the addition of fish oils to mammal diets during lactation benefits milk production, litter growth and the litter immune system, but there is little evidence supporting the use of oils that have been dried using a spray-drying method designed to cool and crystalize fat particles. The objective of this study was to evaluate the effect of a spray-dried dietary fat enriched with EPA and DHA on the fatty acid composition of sow milk. Fifteen pregnant sows were assigned to three dietary treatments from day 100 of gestation until weaning (day 28). Control sows (CONT) were fed an unsupplemented basal diet, and supplemented sows were fed the basal diet plus $20 \mathrm{~g}$ (FOPF20) or $40 \mathrm{~g}$ (FOPF40) of a spray-dried powdered fat enriched with EPA and DHA. Milk and colostrum compositions and milk yield were similar among diets, and the main milk fatty acids (FA) were C14:0, C16:0, C18:0, C18:1 n-9 and C18:2 n-6. Supplementation with EPA and DHA (FOPF20 and FOPF40) decreased the saturated FA contents and increased the amount of polyunsaturated FA. In summary, the results indicated that supplementing sow diets with EPA and DHA could decrease the saturated fatty acid content and increase the polyunsaturated fatty acid content of milk.
\end{abstract}

Key words: Fatty acids, milk, powdered fat, sow, spray-dry.

\section{Introduction}

As in other mammals, n-6 and n-3 series polyunsaturated fatty acids (PUFA) are considered essential for swine because they cannot be endogenously synthesized and must therefore be obtained from the diet (Simopoulos, 1991). The

Received May 25, 2016. Accepted October 26, 2016. Corresponding author: monica.gandarillas@uach.cl addition of fish oil [a preformed source of $n-3$ FA such as eicosapentaenoic (EPA; C20:5 n-3) and docosahexaenoic acids (DHA; C22:6 n-3)] to sow diets has been shown to be beneficial to sucking piglet growth (Luo et al., 2013). EPA and DHA play an important role in the regulation of both immune and reproductive functions because they are precursors for the synthesis of different types of eicosanoids (Mateo et al., 2009). Previous research (Fritsche et al., 1993; 
Rooke et al., 2001; Mateo et al., 2009; Luo et al., 2013) found that supplementing sow diets during lactation with enriched sources of EPA and DHA increases the milk contents of these FAs, which are then transferred to suckling piglets and may increase their growth and improve their immune response. However, none of these previous studies have investigated the response of swine to fish oil that has been transformed into fat in the form of a solid powder. Therefore, the objective of this study was to evaluate the effect of spray-dried dietary fats enriched with sources of EPA and DHA on the fatty acid composition of sow milk.

\section{Materials and methods}

The animals used in this study were housed at the Centro de Investigación, Innovación Tecnológica y Capacitación para la Industria Porcina Nacional (CICAP) located in Pirque, Chile. Animal care procedures followed the guidelines of the Animal Care and Use Committee of the Facultad de Agronomía e Ingeniería Forestal of the Pontificia Universidad Católica de Chile.

\section{Animals and experimental treatments}

The experiment employed a completely randomized design using 3 dietary treatments. Fifteen multiparous sows (Large white $\times$ Landrance, PIC genetics GP 1050, parity 8) were used in the study, which began at $\mathrm{d} 100$ of pregnancy and continued until weaning (d 28 post farrowing). Sows were randomly allocated to dietary treatments (five sows per treatment) that differed in the EPA and DHA contents of the feed. The experimental diets contained 0 (CONT), 20 (FOPF20) and 40 (FOPF40) $\mathrm{g}$ of powdered fat that was high in EPA

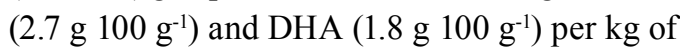
basal gestation or lactation diet, and the powdered fat supplement (FOPF) contained fish oil $(15 \mathrm{~g}$

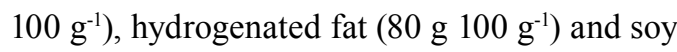

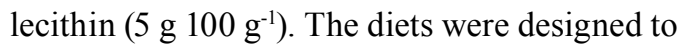
be isoenergetic and isonitrogenous by adding powdered fat that was free of EPA and DHA (PF) to each diet to reach a total of $40 \mathrm{~g}$ powder fat $\mathrm{kg}^{-1}$ of the basal diet; this powdered fat contained

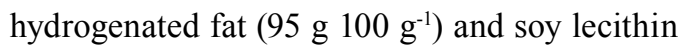

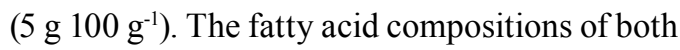
powdered fats are presented in Table 1. The gestation and lactation basal diets had a corn-soybean meal base, and their compositions are presented in Table 2. Diets were designed following NRC (2012) recommendations.

Table 1. Fatty acid composition of powdered fats containing EPA and DHA provided as a supplement to sows from day 100 of gestation to weaning (d 28).

\begin{tabular}{|c|c|c|}
\hline Fatty acid & $\mathrm{PF}^{1}$ & $\mathrm{FOPF}^{2}$ \\
\hline $\mathrm{C} 12: 0$ & 10.43 & 11.13 \\
\hline $\mathrm{C} 14: 0$ & 4.53 & 6.55 \\
\hline C16:0 & 43.11 & 38.50 \\
\hline C18:0 & 0.01 & 0.20 \\
\hline C18:1 n-9 & 0.03 & 0.03 \\
\hline C18:2 n-6 & 37.35 & 30.73 \\
\hline $\mathrm{C} 18: 3 \mathrm{n}-3$ & 0.03 & 0.03 \\
\hline$C 18: 3 n-6$ & 0.02 & 0.06 \\
\hline C20:1 n-9 & 0.00 & 0.05 \\
\hline$C 20: 5 n-3$ & 0.01 & 4.09 \\
\hline $\mathrm{C} 22: 0$ & 0.02 & 0.03 \\
\hline C22:1 n-9 & 0.00 & 0.01 \\
\hline$C 22: 6 n-3$ & 0.06 & 0.38 \\
\hline$\sum$ Saturated fatty acids & 62.27 & 63.36 \\
\hline$\sum$ Monounsaturated fatty acids & 0.18 & 0.45 \\
\hline$\sum$ Polyunsaturated fatty acids & 37.55 & 35.62 \\
\hline Others & 4.40 & 8.23 \\
\hline
\end{tabular}

${ }^{1} \mathrm{PF}=$ powdered fat with hydrogenated fat $\left(95 \mathrm{G}_{\left.100 \mathrm{~g}^{-1}\right) \text { and }}\right.$

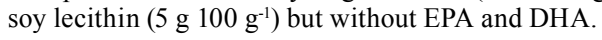

${ }^{2} \mathrm{FOPF}=$ powdered fat supplement containing fish oil $(15 \mathrm{~g}$

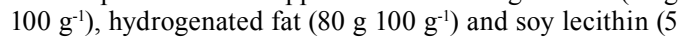
g $\left.100 \mathrm{~g}^{-1}\right)$.

\section{Powdered fat production}

Powdered fats were produced by atomization using a spray dryer (Compact Gas Model NR 28036, APV Anhydro SA, Denmark) that was 
Table 2. Ingredients and chemical compositions of basal gestation and lactation diets.

\begin{tabular}{|c|c|c|}
\hline Item & Gestation & Lactation \\
\hline \multicolumn{3}{|l|}{ Ingredients $\left(\mathrm{g} \mathrm{kg}^{-1}\right)$} \\
\hline Corn & 339.2 & 551.9 \\
\hline Sorghum & 300.0 & 150.0 \\
\hline Rice bran & - & 180.0 \\
\hline Wheat bran & 250.0 & 55.0 \\
\hline Alfalfa & 30.0 & - \\
\hline Yeast & 2.0 & - \\
\hline Soybean meal & 1.3 & 10.5 \\
\hline Soybean & 16.0 & 12.0 \\
\hline Poultry oil & 21.0 & - \\
\hline Lysine & 5.6 & 1.6 \\
\hline Threonine & 1.4 & 1.0 \\
\hline Methionine & 1.0 & 1.0 \\
\hline Phytase & 5.8 & 6.0 \\
\hline Calcium carbonate & 16.0 & 6.0 \\
\hline Salt & 6.0 & - \\
\hline Copper sulfate & 0.5 & - \\
\hline Antioxidant & 0.2 & - \\
\hline Vitamin-mineral mix & 4.0 & 25.0 \\
\hline \multicolumn{3}{|l|}{ Chemical composition (\%) } \\
\hline Dry matter & 88.6 & 88.9 \\
\hline Crude protein & 12.6 & 17.8 \\
\hline Crude fiber & 6.3 & 4.4 \\
\hline Ether extract & 5.3 & 3.1 \\
\hline Ash & 6.1 & 6.4 \\
\hline ME (Mcal /kg) & 3.1 & 3.1 \\
\hline \multicolumn{3}{|l|}{ Fatty acids ( $\mathrm{g} / 100 \mathrm{~g}$ total fatty acids) } \\
\hline $\mathrm{C} 14: 0$ & 0.12 & 0.15 \\
\hline C16:0 & 0.02 & 0.01 \\
\hline C16:1 & 19.45 & 30.46 \\
\hline $\mathrm{C} 18: 0$ & 0.06 & 0.08 \\
\hline C18:1 n-9 & 4.37 & 4.37 \\
\hline C18:2 n-6 & 44.43 & 54 \\
\hline C18:3n-6 & 0.02 & 0.03 \\
\hline C18:3 n-3 & 0.71 & 0.56 \\
\hline $\mathrm{C} 20: 2$ & 0.04 & 0.04 \\
\hline$C 20: 3 n-6$ & 0.02 & 0.01 \\
\hline C20:4 n-6 & 0.34 & 0.61 \\
\hline$C 20: 5 n-3$ & 0.07 & 0.25 \\
\hline $\mathrm{C} 22: 6 \mathrm{n}-3$ & 0.22 & 1.6 \\
\hline $\mathrm{C} 23: 0$ & 0 & 0.03 \\
\hline $\mathrm{C} 24: 0$ & 0.04 & 0.01 \\
\hline C24:1 n-9 & 0.3 & 0.08 \\
\hline$\sum$ Saturated fatty acids & 29.67 & 7.68 \\
\hline$\sum$ Monounsaturated fatty acids & 24.39 & 35.15 \\
\hline$\sum$ Polyunsaturated fatty acids & 45.94 & 57.17 \\
\hline$\sum n-6$ & 44.79 & 54.65 \\
\hline$\sum n-3$ & 1.02 & 2.42 \\
\hline$n-6 / n-3$ ratio & 42 & 22.6 \\
\hline
\end{tabular}

Vitamins and minerals per kilogram of the diet provided by the premix: vitamin A: 3,300,000 UI; vitamin $\mathrm{D}_{3}: 550,000 \mathrm{IU}$; vitamin E: 2,560 IU; vitamin $\mathrm{K}_{3}: 1,400 \mathrm{mg}$; vitamin $\mathrm{B}_{1}: 1,100$ $\mathrm{mg}$; vitamin $\mathrm{B}_{2}: 3,300 \mathrm{mg}$; vitamin $\mathrm{B}_{6}: 1,460 \mathrm{mg}$; vitamin $\mathrm{B}_{1}$ : $1,460 \mathrm{mcg}$; biotin: $51 \mathrm{mg}$; folic acid: $256 \mathrm{mg}$; niacin: 14,600 $\mathrm{mg}$; calcium pantotenate: $11,000 \mathrm{mg}$; choline: $11,000 \mathrm{mg}$; Mn: 15,000 mg; Cu: 5,000 mg; I: $183 \mathrm{mg}$; Zn: 43,333 mg; Fe: $58,333 \mathrm{mg}$; Se: $100 \mathrm{mg}$; calcium carbonate: $1,000,000 \mathrm{mg}$. modified by incorporating a compressor to cool the atmospheric air to $-3 \pm 2{ }^{\circ} \mathrm{C}$ before it entered the atomization chamber, which was maintained at $0 \pm 2{ }^{\circ} \mathrm{C}$. A mixture of fat (and fish oil for FOPF) and emulsifier (soy lecithin) was melted at $80^{\circ} \mathrm{C}$ and injected into the chamber through an atomizer disc (CF-100/28060, APV) rotating at 25000 $\mathrm{rpm}$. A cyclone separator was used to separate the crystallized fat particles from the air, and using a centrifugal fan (CPE-315/50/R, Novenco), the air was then expelled from the drying equipment to collect the powdered fat. The synthesized fat was stored in 5-kg bags and maintained at room temperature until use.

\section{Sow feeding and management}

Each sow received $3 \mathrm{~kg} \mathrm{~d}^{-1}$ of the experimental diets (with the gestation diet as a base) until farrowing (d 0), after which the feed delivery was increased (with the lactation diet as a base) by $0.5 \mathrm{~kg} \mathrm{~d}^{-1}$ until d 3. From $\mathrm{d} 4$ on, the sows had ad libitum access to feed. During lactation, feed intake was determined and recorded weekly. Animals had free access to water throughout the gestation and lactation stages. The sows stayed in individual gestation crates from d 100 to 111 and were moved to the farrowing unit on $\mathrm{d} 112$. The farrowing room temperature was maintained at $17 \pm 2{ }^{\circ} \mathrm{C}$, but supplemental heat was provided for the piglets by heat lamps and floor heating $\left(30 \pm 2^{\circ} \mathrm{C}\right)$.

\section{Milk yield and chemical analysis}

Milk production was estimated on d 7, 14, 21 and 28 of lactation using the weigh-suckle-weigh method (Speer and Cox, 1984). Litters were separated from their dams for $1 \mathrm{~h}$, and the piglets were then weighed to obtain a pre-suckling litter weight (sum of weights of the individual piglets). They were then returned to their mothers and allowed to suckle until synchronized litter suckling ended; the piglets were then immediately weighed to obtain a post-suckling weight. This procedure 
was repeated for four consecutive h. Hourly milk yield was a measurement of litter weight gain due to milk intake and was determined from the difference between the pre- and post-suckling litter weights. The daily milk yield was estimated by multiplying the mean hourly milk yield by 24 .

Colostrum and milk samples were collected by manually milking all functional teats on both sides of the udder. Colostrum $(50 \mathrm{~mL})$ was collected 30 min after the birth of the first piglet, and milk (50 $\mathrm{mL}$ ) was collected on $\mathrm{d} 7,14,21$ and 28 after farrowing. Piglets were prevented from suckling for $1 \mathrm{~h}$ before the samples were obtained. Sows were milked for $3 \mathrm{~min}$ after receiving an intramuscular injection of $2 \mathrm{~mL}$ of oxytocin $\left(10 \mathrm{UI} \mathrm{mL}^{-1}\right)$, and the samples were immediately frozen at $-20{ }^{\circ} \mathrm{C}$ and stored until the analysis of total solids (16.032), crude protein (16.036; Kjeldahl $\mathrm{N} \times 6.38$ ), lactose (31.036) and ash (16.035) following AOAC (1984) procedures; fat content was determined by the Gerber method (British Standards Institution 696, 1969).

\section{Determination of fatty acid composition}

To determine fat composition, each colostrum and milk sample was thawed and mixed in a water bath at $40{ }^{\circ} \mathrm{C}$, and the milk fat was separated using the method proposed by Feng et al. (2004). Ten $\mathrm{mL}$ of raw milk were centrifuged at 6000 rpm for $20 \mathrm{~min}$ at $4{ }^{\circ} \mathrm{C}$ in an Eppendorf 5417R centrifuge, and the fat layer was transferred to a microtube and left at room temperature for 30 min before being centrifuged at 6000 RPM for $20 \mathrm{~min}$ at $20^{\circ} \mathrm{C}$. After the second centrifugation, the top layer was removed and stored at $-20{ }^{\circ} \mathrm{C}$ until FA analysis. Lipids were extracted from the powdered fats and basal diets (both gestation and lactation) by adapting the method of Bligh and Dyer (1959). The FA composition of the powdered fats, basal diets, colostrum and milk were analyzed by gas chromatography. Lipids were methylated following the method of Christie (1982) with the modifications by Chouinard et al. (1999), and all chemicals and solvents used for this method were of analytical grade. A GC-2010 system (Shimadzu Scientific Instruments AOC-20s, Columbia, MD, USA) equipped with a 100-m column (100-m $\times$ $0.32-\mathrm{mm} \times 0.20-\mu \mathrm{m}$ Rtx column) was used with the following conditions. The oven temperature was initially set at $110^{\circ} \mathrm{C}$ for 4 min after injection and then increased to $240{ }^{\circ} \mathrm{C}\left(20^{\circ} \mathrm{C} \mathrm{min}^{-1}\right)$ with an equilibration time of $2 \mathrm{~min}$. The inlet and flameionization detector temperatures were $260^{\circ} \mathrm{C}$; the split ratio was $15: 1$; and a $2-\mu \mathrm{L}$ injection volume was used. The flow of the hydrogen carrier gas to the detector was $25 \mathrm{~mL} \mathrm{~min}^{-1}$; airflow was $400 \mathrm{~mL}$ $\mathrm{min}^{-1}$; and the flow of the nitrogen makeup gas was $40 \mathrm{~mL} \mathrm{~min}^{-1}$. Fatty acid peaks were identified using a fatty acid methyl ester standard (FAME; Supelco 37 Component FAME mix, Bellefonte, PA, USA).

\section{Statistical analysis}

Data were analyzed as a completely randomized design using the GLM procedure in Statistical Analysis Systems software (SAS Institute Inc., Cary, NC, USA). The model included dietary treatment $(0,20,40 \mathrm{~g}$ powdered fat high in EPA and DHA). The Student-Newman-Keuls (SNK) method was used for mean comparisons, and the level of significance was $\mathrm{P} \leq 0.05$.

\section{Results}

\section{Lactation performance}

Total milk yield $(176 \pm 8 \mathrm{~kg})$ and daily feed intake $\left(6 \pm 0.2 \mathrm{~kg} \mathrm{~d}^{-1}\right)$ were not affected by the treatments. Piglet characteristics including mortality $(19 \pm$ $3.3 \%)$, birth weight $(1 \pm 0.03 \mathrm{~kg})$, and weaning weight $(8 \pm 0.2 \mathrm{~kg})$ were also not affected by the treatments $(\mathrm{P}>0.05)$ (Table 3$)$.

\section{Colostrum and milk composition}

The dietary treatments did not affect colostrum and milk composition ( $\mathrm{P}>0.05)$ (Table 4). 
Table 3. Influence of dietary eicosapentaenoic (EPA) and docosahexaenoic (DHA) on sow feed intake, milk yield and piglet performance throughout the 28 days of lactation ${ }^{1}$.

\begin{tabular}{|c|c|c|c|c|c|}
\hline Parameter & $\mathrm{CONT}^{2}$ & FOPF $20^{3}$ & FOPF $40^{4}$ & SEM $^{5}$ & P-value \\
\hline \multicolumn{6}{|l|}{ Sow characteristics } \\
\hline Average daily intake $\left(\mathrm{kg} \mathrm{d}^{-1}\right)$ & 5.52 & 5.80 & 5.93 & 0.274 & 0.836 \\
\hline Total milk yield (kg) & 166.74 & 178.58 & 182.70 & 12.966 & 0.882 \\
\hline \multicolumn{6}{|l|}{ Piglet characteristics } \\
\hline Piglet mortality (\%) & 17.78 & 18.80 & 19.52 & 3.313 & 0.979 \\
\hline Birth weight (kg) & 1.47 & 1.31 & 1.37 & 0.036 & 0.218 \\
\hline Weaning weight (kg) & 8.88 & 8.46 & 7.79 & 0.193 & 0.637 \\
\hline Average dairy gain $\left(\mathrm{kg} \mathrm{d}^{-1}\right)$ & 0.26 & 0.26 & 0.26 & 0.006 & 0.752 \\
\hline
\end{tabular}

${ }^{1}$ There were 5 sows per dietary treatment.

${ }^{2} \mathrm{CONT}=$ control diet without FOPF (powdered fat with EPA and DHA).

${ }^{3} \mathrm{FOPF} 20=$ diet with $20 \mathrm{~g}$ of FOPF per $\mathrm{kg}$ basal diet.

${ }^{4} \mathrm{FOPF} 40=$ diet with $40 \mathrm{~g}$ of FOPF per $\mathrm{kg}$ basal diet.

${ }^{5} \mathrm{SEM}=$ standard error of the mean.

Table 4. Influence of dietary eicosapentaenoic (EPA) and docosahexaenoic (DHA) on the colostrum and milk composition of sows supplemented from day 100 of gestation until weaning $(\mathrm{d} 28)^{1}$.

\begin{tabular}{|c|c|c|c|c|c|c|}
\hline & $\begin{array}{c}\text { Day of } \\
\text { lactation }\end{array}$ & $\mathrm{CONT}^{2}$ & $\begin{array}{l}\text { Sow diet } \\
\text { FOPF } 20^{3}\end{array}$ & FOPF $40^{4}$ & $\mathrm{SEM}^{5}$ & P-value \\
\hline \multicolumn{7}{|c|}{ Crude protein $(\%)$} \\
\hline Colostrum & 0 & 14.96 & 15.65 & 14.62 & 0.596 & 0.779 \\
\hline \multirow[t]{4}{*}{ Milk } & 7 & 5.11 & 4.81 & 4.93 & 0.159 & 0.755 \\
\hline & 14 & 5.11 & 4.91 & 4.94 & 0.157 & 0.854 \\
\hline & 21 & 5.05 & 5.67 & 4.47 & 0.273 & 0.306 \\
\hline & 28 & 5.15 & 5.39 & 5.24 & 0.101 & 0.660 \\
\hline \multicolumn{7}{|l|}{ Lactose (\%) } \\
\hline Colostrum & 0 & $\mathrm{ND}^{6}$ & $\mathrm{ND}^{6}$ & $\mathrm{ND}^{6}$ & & \\
\hline \multirow[t]{4}{*}{ Milk } & 7 & 4.70 & 4.70 & 4.67 & 0.118 & 0.992 \\
\hline & 14 & 4.83 & 4.45 & 4.47 & 0.140 & 0.501 \\
\hline & 21 & 4.98 & 4.65 & 5.65 & 0.144 & 0.120 \\
\hline & 28 & 4.70 & 4.60 & 4.60 & 0.052 & 0.706 \\
\hline \multicolumn{7}{|l|}{ Fat $(\%)$} \\
\hline Colostrum & 0 & 5.78 & 4.25 & 4.80 & 0.360 & 0.267 \\
\hline \multirow[t]{4}{*}{ Milk } & 7 & 6.73 & 7.25 & 6.23 & 0.300 & 0.473 \\
\hline & 14 & 7.47 & 8.80 & 8.30 & 0.351 & 0.335 \\
\hline & 21 & 7.35 & 7.82 & 7.00 & 0.247 & 0.473 \\
\hline & 28 & 7.27 & 7.20 & 6.20 & 0.741 & 0.801 \\
\hline
\end{tabular}

${ }^{1}$ There were 5 sows per dietary treatment.

${ }^{2} \mathrm{CONT}=$ control diet without FOPF (powdered fat with EPA and DHA).

${ }^{3} \mathrm{FOPF} 20=$ diet with $20 \mathrm{~g}$ of FOPF per kg basal diet;

${ }^{4} \mathrm{FOPF} 40=$ diet with $40 \mathrm{~g}$ of FOPF per kg basal diet;

${ }^{5} \mathrm{SEM}=$ standard error of the mean;

${ }^{6} \mathrm{ND}=$ not detected. 


\section{Milk fatty acid composition}

As expected, the concentrations of EPA and DHA in the milk increased with the supplemented diets compared to the control diet $(\mathrm{P} \leq 0.05)$. As the concentrations of EPA and DHA increased, the concentration of saturated FA decreased while that of monounsaturated FA increased (Table 5).

\section{Discussion}

Modern pig production systems demand highly prolific sows with a high milk production, and adding fat with essential fatty acids as a dietary supplement supports these requirements (Rosero et al., 2016). Moreover, lactating sow diets without essential fatty acid supplementation can result in a negative balance of linoleic and linolenic acids
(Rosero et al., 2016). Thus, the objective of this study was to evaluate the effect of spray-dried dietary fats enriched with sources of EPA and DHA, an alternative fat supplementation approach during lactation, on the fatty acid composition of sow milk.

Fat supplementation at the level of $10 \%$ of the diet improves litter weight and piglet survival (Seerley et al., 1981). In terms of lactation performance and consistent with the results of Mateo et al. (2009), milk components such as lactose, protein and fat were not affected by the dietary treatments in this study. However, Rosero et al. (2015) found greater lipid excretion in the milk of fat-supplemented sows relative to non-supplemented sows, whereas Eastwood et al. (2014) found no improvement in performance when adding EPA to a sow diet. However, the increases in the milk EPA and DHA

Table 5. Influence of dietary eicosapentaenoic (EPA) and docosahexaenoic (DHA) on milk fatty acid composition ${ }^{1}$.

\begin{tabular}{lccccc}
\hline Fatty acid (g $100 \mathrm{~g}^{-1}$ of fatty acids) & CONT $^{2}$ & FOPF20 & FOPF40 & SEM $^{5}$ & P-value \\
\hline C14:0 & 2.74 & 2.68 & 2.52 & 0.405 & 0.190 \\
C16:0 & 25.27 & 24.69 & 23.65 & 0.573 & 3.872 \\
C16:1 & 0.89 & 1.04 & 1.31 & 0.451 & 0.031 \\
C18:0 & 2.34 & 1.60 & 1.12 & 0.372 & 0.256 \\
C18:1 n-9 & 22.10 & 19.27 & 20.58 & 2.782 & 0.438 \\
C18:2 n-6 & 38.11 & 35.13 & 24.10 & 2.963 & 0.112 \\
C18:3 n-6 & 0.46 & 0.79 & 0.46 & 0.310 & 0.421 \\
C18:3 n-3 & 0.76 & 1.50 & 1.18 & 0.298 & $<0.001$ \\
C20:2 & 0.91 & 1.15 & 1.73 & 0.708 & 0.152 \\
C20:3 n-6 & 0.44 & 0.45 & 0.99 & 0.353 & 0.579 \\
C20:5 n-3 & 0.98 & 1.33 & 2.41 & 0.652 & $<0.001$ \\
C20:6 n-6 & 0.83 & 0.64 & 0.78 & 0.302 & 0.044 \\
C22:6 n-3 & 0.90 & 6.75 & 13.21 & 2.977 & $<0.001$ \\
C23:0 & 1.48 & 1.02 & 1.52 & 0.721 & 0.658 \\
C24:0 & 0.48 & 0.43 & 0.64 & 0.335 & 0.059 \\
C24:1 n-9 & 1.40 & 1.48 & 3.76 & 1.178 & $<0.001$ \\
\&Saturated fatty acids & 32.30 & 30.40 & 29.42 & 1.587 & $<0.001$ \\
\&Monounsaturated fatty acids & 24.38 & 21.79 & 25.66 & 2.737 & 0.299 \\
\&Polyunsaturated fatty acids & 43.32 & 47.81 & 44.92 & 3.368 & $<0.001$ \\
\hline
\end{tabular}

${ }^{1}$ There were 5 sows per dietary treatment.

${ }^{2} \mathrm{CONT}=$ control diet without FOPF (powdered fat with EPA and DHA).

${ }^{3} \mathrm{FOPF} 20=$ diet with $20 \mathrm{~g}$ of FOPF per $\mathrm{kg}$ basal diet.

${ }^{4} \mathrm{FOPF} 40=$ diet with $40 \mathrm{~g}$ of FOPF per $\mathrm{kg}$ basal diet.

${ }^{5} \mathrm{SEM}=$ standard error of the mean. 
contents of sows fed the FOPF20 and FOPF40 treatments compared with the unsupplemented diet in this study are consistent with previous reports (Jensen et al., 2000; Mateo et al., 2009). The main milk FAs found in this study were C14:0, C16:0, C18:0, C18:1 n-9 and C18:2 n-6, which is consistent with Lauridsen and Danielsen (2004), and our dietary treatments also decreased the saturated FA contents while increasing polyunsaturated FA. Eastwood et al. (2014) observed increased EPA in sow milk following ALA supplementation. Yao et al. (2012) demonstrated that altering the PUFA ratio from n-6:n-3 to 9:1 in the diet of lactating sows influenced immunoglobulin and cytokine levels and tended to increase litter performance and piglet immune status.

The average daily gain by the piglets and the feed intake by the sows were not affected by the dietary treatments; this concurs with the findings reported by Smits et al. (2011), who supplemented sow diets with $2.9 \mathrm{~g} \mathrm{~d}^{-1}$ of EPA + DHA from $\mathrm{d} 107$ of gestation until weaning (d 19) and found no change in piglet BW gain. However, those authors observed interesting effects in the subsequent parity. Additionally, Leonard et al. (2010) found no changes in the average daily gain in piglets when sows were fed $39 \mathrm{~g} \mathrm{~d}^{-1}$ of EPA and $24 \mathrm{~g} \mathrm{~d}^{-1}$ of DHA from d 109 of gestation until weaning (d 26). However, a positive response to higher doses was found by Luo et al. (2013), who reported that supplementing sow diets with $7.41 \mathrm{~g} \mathrm{~kg}^{-1}$ of EPA and $4.38 \mathrm{~g} \mathrm{~kg}^{-1}$ of DHA $10 \mathrm{~d}$ before farrowing until $28 \mathrm{~d}$ of lactation increased the BW gain in weanling pigs ( $\mathrm{d} 35$ to 70 ) compared to sow diets without $n-3$ supplementation. This study focused on milk fatty acid composition, so more research is needed on the effect of sow diet supplementation with EPA and DHA on piglet performance parameters in a larger number of animals.

The main conclusion of this study is that supple-

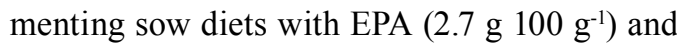

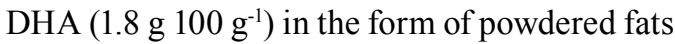
could decrease milk saturated fatty acid contents and increase polyunsaturated fatty acid contents without affecting milk composition. Studies involving higher concentrations of EPA and DHA in sow diets and a larger number of both sows and piglets are required to detect changes in the performance of weanling pigs.

\section{Acknowledgments}

The authors acknowledge the financial support of the Fundación para la Innovación Agraria (FIA; PYT-2011-0057). We thank the staff of the Centro de Investigación, Innovación Tecnológica y Capacitación para la Industria Porcina Nacional (CICAP) for caring for the animals throughout the study and for their technical support. We would also like to thank Juanita Clavijo, Jorge Manzor and Matías Pasache of the Departamento de Ciencias Animales of the Pontificia Universidad Católica de Chile for their assistance in the laboratory.

\section{Resumen}

M. Grez, M. Gandarillas, F. González y E. Vargas-Bello-Pérez. 2016. Influencia de EPA y DHA dietarios sobre el perfil de ácidos grasos de leche de cerda. Cien. Inv. Agr. 43(3): 347-355. El objetivo de este estudio fue evaluar el efecto de fuentes dietarias enriquecidas con EPA y DHA (Ácidos eicosapentaenoico y docosahexaenoico) sobre el perfil de ácidos grasos de leche de cerda. Quince cerdas preñadas fueron repartidas en tres tratamientos desde el día 100 de gestación hasta el destete de lechones (día 28). Las cerdas del grupo control (CONT) fueron alimentadas con una dieta basal sin suplemento de EPA y DHA. Las cerdas alimentadas con dietas suplementadas recibieron una dieta basal con $20 \mathrm{~g}$ (FOPF20) o $40 \mathrm{~g}$ (FOPF40) de grasa en polvo enriquecida con EPA y DHA. La composición de leche y calostro y la producción de leche de las cerdas fueron similares entre tratamientos. Los principales ácidos grasos en 
leche fueron: C14:0, C16:0, C18:0, C18:1 n-9 y C18:2 n-6. La suplementación con EPA y DHA (FOPF20 y FOPF40) disminuyó el contenido de ácidos grasos saturados e incrementó poliinsaturados. En resumen, los resultados indicaron que la suplementación de dietas de cerdas con EPA y DHA puede disminuir el contenido de ácidos grasos saturados e incrementar contenido de ácidos grasos poliinsaturados.

\section{References}

AOAC-Association of Official Analytical Chemistry. 1984. Official Methods of Analysis. 13th ed. Washington, D.C., USA.

Bligh, E.G., and W.J. Dyer. 1959. A rapid method of total lipid extraction and purification. Can. J. Biochem. Phys. 37:911-917.

British Standards Institution, 1969. British Standards 696. I. Apparatus, London (UK). British Standard House. 29 pp.

Chouinard, P.Y., L. Corneau, D.M. Barbano, L.E. Metzger, and D.E. Bauman. 1999. Conjugated linoleic acids alter milk fatty acid composition and inhibit milk fat secretion in dairy cows. J. Nutr. 29:1579-1584.

Christie, W.W. 1982. A simple procedure for rapid transmethylation of glycerolipids and cholesteryl esters. J. Lipid Res. 23:1072-1075

Eastwood, L., P. Leterme, and A.D. Beaulieu. 2014. Changing the omega- 6 to omega-3 fatty acid ratio in sow diets alters serum, colostrum, and milk fatty acid profiles, but has minimal impact on reproductive performance. J. Anim. Sci. 92(12):5567-82.

Feng, S., A.L. Lock, and P.C. Garnsworthy. 2004. A rapid lipid separation method for determining fatty acid composition of milk. J. Dairy Sci. 87:3785-3788.

Fritsche, K.L., S.C. Huang, and N.A. Cassity. 1993. Enrichment of omega-3 fatty acids in sucking pigs by maternal dietary fish oil supplementation. J. Anim. Sci. 71:1841-1847.

Jensen, C.L., M. Maude, R.E. Anderson, and W.C. Heird. 2000. Effect of docosahexaenoic acid supplementation of lactating women on the fatty acid composition of breast milk lipids and maternal and infant plasma phospholipids. Am. J. Clin. Nutr. 71:292S-299S.
Lauridsen, C., and V. Danielsen. 2004. Lactational dietary fat levels and sources influence milk composition and performance of sows and their progeny. Livest. Prod. Sci. 91:95-105.

Leonard, S.G., T. Sweeney, B. Bahar, B.P. Lynch, and J.V. O'Doherty. 2010. Effect of maternal fish oil and seaweed extract supplementation on colostrum and milk composition, humoral response, and performance of suckled piglets. J. Anim. Sci. 88:2988-2997.

Luo, J., F. Huang, C. Xiao, Z. Fang, J. Peng, and S. Jiang. 2013. Responses of growth performance and proinflammatory cytokines expression to fish oil supplementation in lactating sows' and/or weaned piglets' diets. Biomed. Res. International vol. 2013. Article ID 905918. 9 pp.

Mateo, R.D., J.A. Carroll, Y. Hyun, S. Smith, and S.W. Kim. 2009. Effect of dietary supplementation of n-3 fatty acids and elevated concentrations of dietary protein on the performance of sows. J. Anim. Sci. 97:948-959.

NRC. 2012. Nutrient Requirements of Swine, 11th ed. Natl. Acad. Press. Washington, DC, USA.

Rooke, J.A., A.G. Sinclair, S.A. Edwards, R. Cordoba, S. Pkiyach, P.C. Penny, P. Penny, A.M. Finch, and G.W. Horgan. 2001. The effect of feeding salmon oil to sows throughout pregnancy on pre-weaning mortality of piglets. J. Anim. Sci. 73:489-500.

Rosero, D.S., J. Odle, S.M. Mendoza, R.D. Boyd, V. Fellner, and E. van Heugten. 2015. Impact of dietary lipids on sow milk composition and balance of essential fatty acids during lactation in prolific sows. J. Anim. Sci. 93:29352947.

Simopoulos, A.P. 1991. Omega-3 fatty acids in health and disease and in growth and development. Am. J. Clin. Nutr. 54:438-463. 
Seerley, R.W., Snyder, R.A., and McCampbell H.C. 1981. The influence of sow dietary lipids and choline on piglet survival, milk and carcass composition. J.Anim.Sci. 52:542-550.

Smits., R.J., B. G. Luxford, M. Mitchell, and M. B. Nottle. 2011. Sow litter size is increased in the subsequent parity when lactating sows are fed diets containing n-3 fatty acids from fish oil. J. Anim. Sci. 89:2731-2738.
Speer, V.C., and D.F. Cox. 1984. Estimating milk yield of sows. J. Anim. Sci. 59:1281-1285.

Yao W., J. Li, J.J. Wang, W. Zhou, Q. Wang, R. Zhu, F. Wang, and P. Thacker P. 2012. Effects of dietary ratio of n-6 to n-3 polyunsaturated fatty acids on immunoglobulins, cytokines, fatty acid composition, and performance of lactating sows and suckling piglets. J. Anim. Sci. Biotechnol. 3:43. 